\title{
Arrangement of the foundations under the new hotel in Lviv
}

\author{
Andrii Kramarchuk ${ }^{1}$, Borys Ilnytskyy ${ }^{1}$, and Oksana Lytvyniak $^{2 *}$ \\ ${ }^{1}$ Department of Building Constructions and Bridges, Institute of Building and Environmental \\ Engineering, Lviv Polytechnic National University, Ukraine \\ ${ }^{2}$ Department of Civil Safety, Viacheslav Chornovil Institute of Sustainable Development, Lviv \\ Polytechnic National University
}

\begin{abstract}
The paper discusses a renovation technique of a historic housing system used in Lviv. The technique presented involves an arrangement of foundations including conservation, as well as displaying exposed fragments of ancient buildings. The foundations of a hotel complex are accomplished owing to drilled injection piers. There are also full-scale tests of drilled injection piers on axial static pressed load which are carried out on the construction site.
\end{abstract}

\section{Introduction}

The building of a hotel complex on the corner of Krakivska and Virmenska streets in Lviv was supposed to begin in 2004, when the executive committee of Lviv borough council adopted the solution concerning the reproduction of the lost historical housing system of north commercial city block within the area of these streets. Later, this area was allotted for a housing system of a hotel complex. The $868 \mathrm{~m}^{2}$ space under the building and the plot of land under the hotel is located in the area of protection of cultural monuments by UNESCO.

In 2010 Lviv borough council and company «Budinvest» organized international architectural contest for a project of a hotel complex in terms of regeneration of historical city block. The winner of the contest was an Austrian architect German Gubert. His project, however, was approached critically by the citizens of Lviv because of the uncharacteristic architectural solution for the urban core and the form of object. After some public protests and public hearings, the investor refused the realization of Gubert's architectural project. In 2010, a new project of hotel was launched by architects of a research-and-development laboratory; which operates under the Department of Restoration of Architectural and Artistic Heritage of Lviv Polytechnic National University. The resources for the project were provided by the investor. At the same time, the realization of project became complicated because of fragments of building foundations dating back to the XVI - XVII century which were discovered during archeological digs on the corner Krakivska and Virmenska street (Fig. 1).

\footnotetext{
* Corresponding author: lytvyniak.oksana@gmail.com
} 


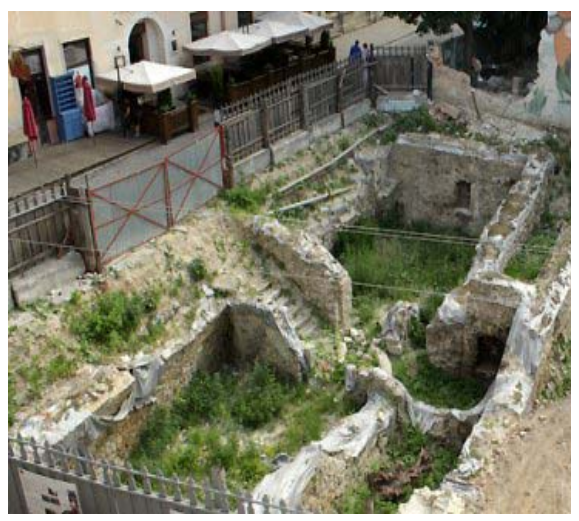

Fig. 1. The discovered pieces of foundation of a building.

The new project, which is developed by main architect of Lviv - Yurij Dubyk - in coauthorship with colleagues from Lviv Polytechnic National University, is a reproduction of a lost historical building belonging to a hotel complex in terms of a renovation project of this city block. It complies to the rules of the construction concernig a regeneration of a historical city block with elements form the mid-XIX century used in the elevation (Fig. 2, 3). When Yurij Dubyk presented this project he said, «During the development of this project we used existing documents in historical archives about architectural special features of buildings in this part of city and the parceling, in other words planning out site of model of XVI-XVII centuries. Primary at the corner streets Krakivska-Virmenska were four buildings with superficiality in three or four floors. Then the planning out of site under the object will focus on the parceling of XVI-XVII centuries. We took the solution to use in elevation of future hotel architectural models by middle of XIX century to save the interior of historical epoch».

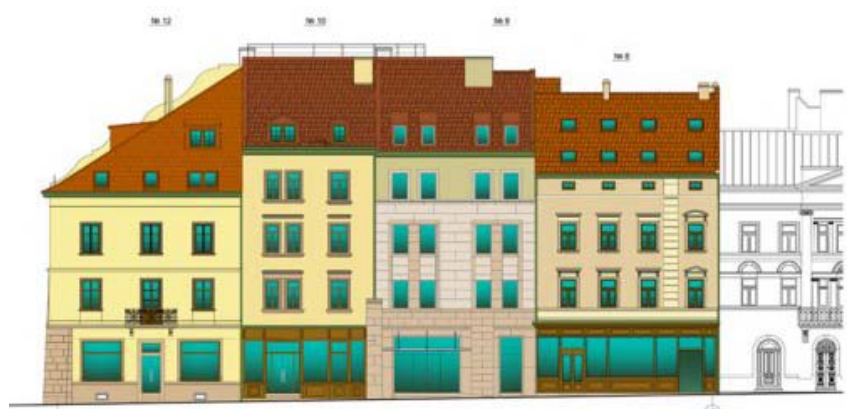

Fig. 2. The elevation of hotel (the look of Krakivska Str. ).

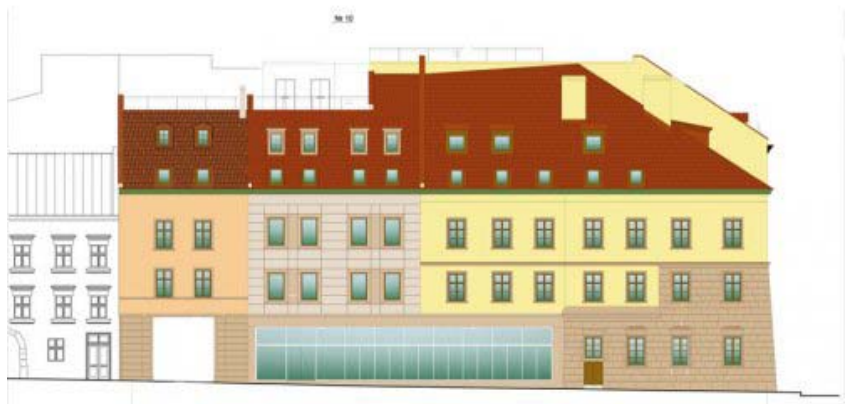

Fig. 3. The elevation of hotel (the look of Virmenska Str.). 


\section{Experimental investigations}

\subsection{Basic information}

The methodology of renovation of a lost housing system in a historical city center is actively discussed among architect-restorers, guards of monuments, historians and the community. They cannot give the right solution whether to restore or to keep the places of lost housing system as free orderly urban territories. All in all, global city planning and architectural practice find different approaches to decide about similar problems in terms of requirements and the strategy of city development. Particularly, the methods of renovation of historical edifices which were destroyed or damaged as a result of war operations were interrogated by researchers of states. Especially, after Second World War in Warsaw, Wroclaw, Elblong not just individual edifices were built, but the whole city blocks in places where lost city housing system was located. Accordingly, these architectural transformations found their arguments in theoretical researches. Famous Polish explorers Edmund Małachowicz described several methods, which are used for similar models of transformation, that is reintegration, reconstruction, reproduction, and restitution. Which one to chose depends on the status of a territory, the technical condition of protected building fragments, the building standards [1].

Besides, the dictates of [2] foresee the use of the regeneration principle in architectural projecting for protected territories.

The main aim of this investigation was to design the arrangement of the foundations with conservation and displaying exposed fragments of ancient buildings. The complication which arose was that the foundation fragments occurred on different benchmarks and now they have different physical-mechanical characteristics because of the use of different materials for their considerable age.

\subsection{Additional information}

It was determined in the project that the arrangement of the foundations ought to be done with compliance to the law, and, at the same time, maximum conservation should be done and historic fragments of the building should be exposed (Fig. 1). However, geological conditions of the building site complicated the solution of this problem. The existent foundations had different physical-mechanical characteristics because different materials was used for them over time, besides, they had different depth, and they were built on manmade grounds. At the same time, natural grounds, which could become a base (semi-solid clay and semi-rocky ground - marl under clay), dropped by $4.5 \mathrm{~m}$ in terms of building site limits. In the other words, the grounds came under the base of separate foundations in one part of the building site; however, they did not come under the base of foundations by $5.4 \mathrm{~m}$ in another part of the building site.

Thereby, a solution was created to drill injection piers with diameter $600 \mathrm{~mm}$ under on marl. Afterwards, high grillage was made on the drilled injection piers in the form of monolithic reinforced concrete slab. There also was floor slab over basement- which was constructed from restored exposed fragments of ancient buildings. The choice of the piers by diameter $600 \mathrm{~mm}$ was executed of following conditions: physical-mechanical characteristics of base's grounds and possibility to use building technique under conditions of historical housing system. The scheme of pile foundations was shown in Fig. 4.

Calculated load on piers was up to $2500 \mathrm{kN}$. The reinforcement of piers was a spatial framework. It was constructed with twelve longitudinal steel reinforcements of $25 \mathrm{~mm}$ diameter and transverse (circular) steel reinforcement of $6 \mathrm{~mm}$ diameter with a pitch of $200 \mathrm{~mm}$. 


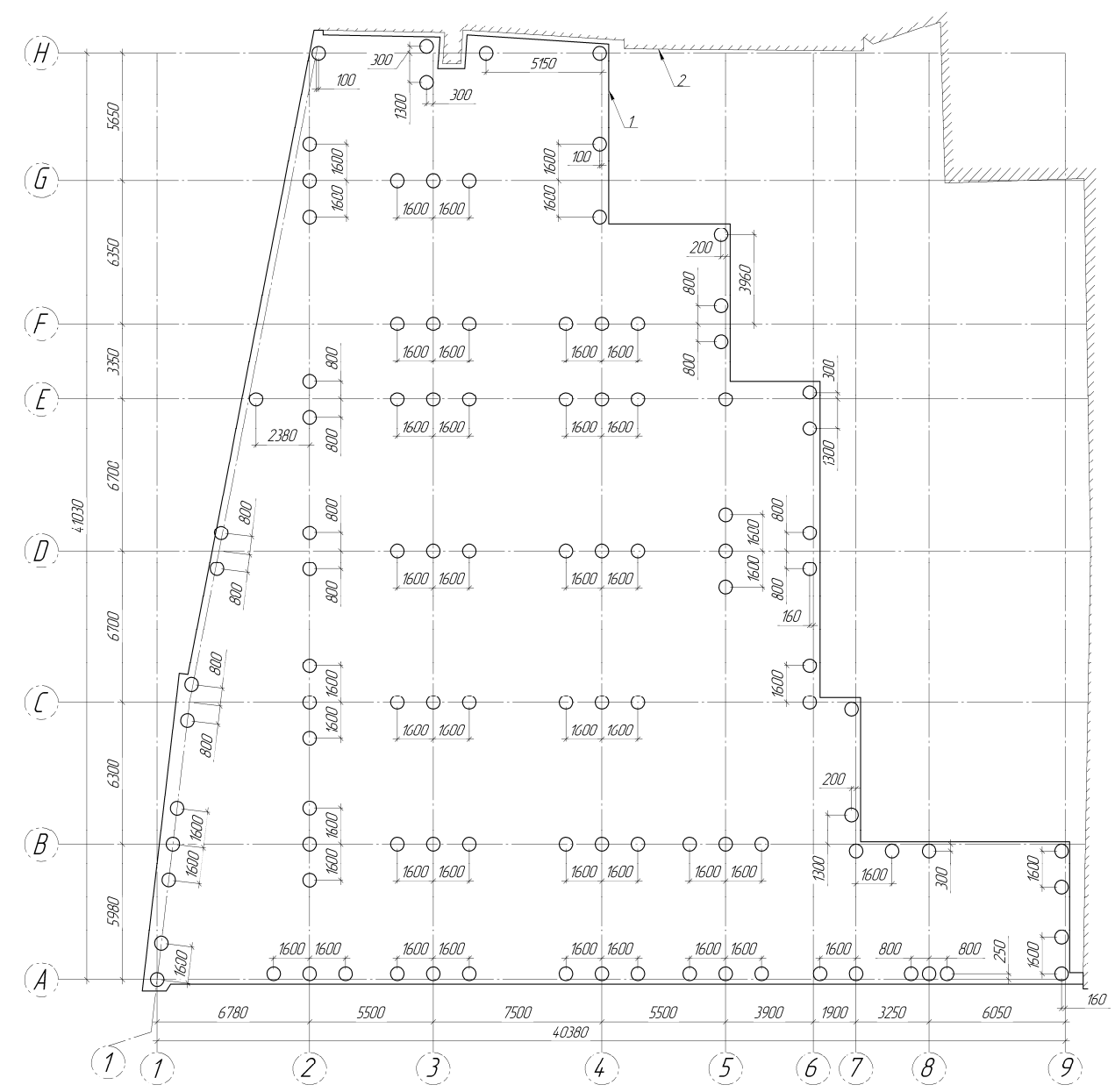

Fig. 4. The scheme of pier foundations: 1 - outer contour of hotel complex; 2 - boundary of existing house system.

\section{Results and discussion}

Full-scale test of piers was conducted with a maximum loading of $3000 \mathrm{kN}$ on a pier on the construction site. The experiments were carried out according to the standards of [4] test of piers on axial static pressed load. The pier PK-1 during the test and test bench are shown in Fig. 5.

The test of the pier was carried out with the scheme for pier trial [4] by means of twelve anchor piers, two control traverses and one power traverse, which were supported by two hydraulic jacks (Fig. 4). The two hydraulic jacks were used for loading on piers which allowed developing the force $4000 \mathrm{kN}$. The tests were carried out stepped load of pier trial to proof of pressed load $3000 \mathrm{kN}$. 


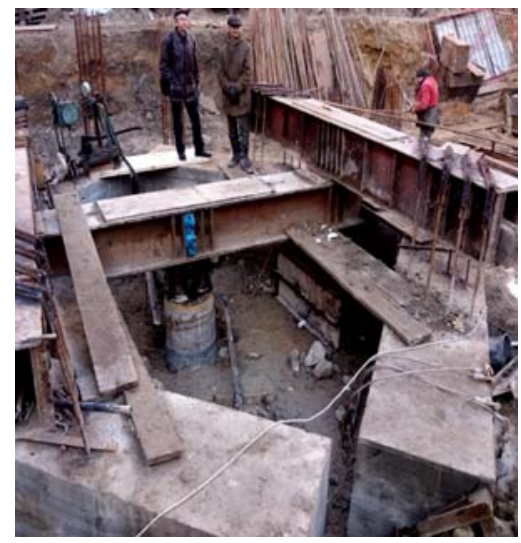

Fig. 5. The test bench for trial of a pier.

There were provided experimental piers, which were subjected to static load, eleven step loads (a range of $240 \ldots 350 \mathrm{kN}$ ) according to [4] (Table 1).

Table 1. Static test of piers.

\begin{tabular}{|c|c|c|c|c|c|c|c|c|c|c|c|}
\hline Step & 1 & 2 & 3 & 4 & 5 & 6 & 7 & 8 & 9 & 10 & 11 \\
\hline $\begin{array}{c}\text { Display of } \\
\text { manometer, } \\
\text { kilogram } \\
\text { force/cm }\end{array}$ & 40 & 70 & 100 & 130 & 160 & 190 & 220 & 250 & 280 & 310 & 340 \\
\hline $\begin{array}{c}\text { Loading, } \\
\mathrm{kN}\end{array}$ & 290 & 560 & 800 & 1080 & 1340 & 1600 & 1860 & 2120 & 2380 & 2650 & 3000 \\
\hline $\begin{array}{c}\text { Total loading, } \\
\mathrm{kN}\end{array}$ & 290 & 850 & 1650 & 2730 & 4070 & 5670 & 7530 & 9650 & 12030 & 14680 & 17680 \\
\hline
\end{tabular}

The movement of pier was measured by deflection indicator. Real movement of a pier was calculated as a value of index of two deflection indicators.

The reading was carried out by all measuring instruments in the following sequence:

- zero reading - before loading on pier;

- first reading - immediately after application of loading, then consistently with an interval of 30 minutes to stabilize the deformation; which did not exceed $0.1 \mathrm{~mm}$;

- following readings - a similar procedure, as described earlier.

The results of a field testing of pier PK-1, PK-2 with a static pressed load are shown in Table 2.

Table 2. Static pressed load of piers by loading.

\begin{tabular}{|c|c|c|c|}
\hline Step & Loading, $\mathrm{P}, \mathrm{kN}$ & $\begin{array}{c}\text { Average pier settlement PK-1, } \\
\mathrm{S}, \mathrm{mm}\end{array}$ & $\begin{array}{c}\text { Average pier settlement PK-2, } \\
\mathrm{S}, \mathrm{mm}\end{array}$ \\
\hline 1 & 290 & 0.00 & 0.00 \\
\hline 2 & 560 & 0.12 & 0.12 \\
\hline 3 & 800 & 0.22 & 0.21 \\
\hline 4 & 1080 & 0.41 & 0.40 \\
\hline 5 & 1340 & 0.66 & 0.65 \\
\hline 6 & 1600 & 0.90 & 0.88 \\
\hline 7 & 1860 & 1.28 & 1.26 \\
\hline 8 & 2120 & 1.58 & 1.56 \\
\hline 9 & 2380 & 2.02 & 2.00 \\
\hline 10 & 2650 & 2.46 & 2.44 \\
\hline 11 & 3000 & 3.37 & 3.36 \\
\hline
\end{tabular}


The experimental piers were loaded after 28 days their arrangements (the demand of [4]. For example, the experimental pier PK-1 was loaded on 22nd January 2016 (the pier PK-1 on 03 November 2015), the experimental pier PK-2 was loaded on 29th January 2016 (the pier PK-2 on 17 November 2015).

The stabilization of experimental piers' deformation was taken by value increase of deformation not more $0.1 \mathrm{~mm}$ for last two observations [4]. The values of average pier settlement by maximum pressed load are shown in Table 3.

Table 3. Average piers settlement by maximum pressed loading.

\begin{tabular}{|c|c|c|c|c|c|}
\hline $\begin{array}{c}\text { Number } \\
\text { of test }\end{array}$ & $\begin{array}{c}\text { Number of pier } \\
\text { by project }\end{array}$ & $\begin{array}{c}\text { Length of } \\
\text { pier, } \mathrm{m}\end{array}$ & $\begin{array}{c}\text { Diameter of } \\
\text { pier, } \mathrm{mm}\end{array}$ & $\begin{array}{c}\text { Final test of pier } \\
\text { by loading, } \mathrm{kN}\end{array}$ & $\begin{array}{c}\text { Average } \\
\text { settlement, } \\
\mathrm{mm}\end{array}$ \\
\hline 1 & PK-1 & 11.0 & 600 & 3000 & 3.37 \\
\hline 2 & PK-2 & 11.9 & 600 & 3000 & 3.36 \\
\hline
\end{tabular}

\section{Conclusions}

The results of the $600 \mathrm{~mm}$ diamerer pier test- which were performed with the use of the drilled injection method on the building site of a hotel complex at the corner Krakivska and Virmenska Street in Lviv showed the value of average settlement of test piers with a maximum loading which exceeds $16.85 \%$ of limit value of an average pier settlement by $20 \mathrm{~mm}$ (according to [3]). Thus, the undertaken constructive solution allow to keep the fragments of ancient buildings while retaining the neccessary bearing capacity of their structure.

\section{References}

1. Małachowicz E. Konserwacja i rewaloryzacja architektury w środowisku kulturowym (Oficyna Wydawnicza Politechniki Wrocławskiej, Wrocław, 2007)

2. DBN 360-92, Town planning. Planning and development of urban and rural settlements (Ukraina, 2002)

3. DBN V.2.1-10:2009, Basements and foundations of buildings (Ukraina, 2009)

4. DSTU B.V.2.1-95, Soils. The methods of field trials by piers (Ukraina, 1995) 